\title{
CD25+CCR4+ cells as a marker of HTLV-1-infected cells in peripheral blood
}

\author{
Huseini Kagdi', Anat Melamed, Silva Hilburn, Maria A Demontis, Charles Bangham, Graham Taylor \\ From 16th International Conference on Human Retroviruses: HTLV and Related Viruses \\ Montreal, Canada. 26-30 June 2013
}

The diagnosis of Human T cell Lymphotropic Virus type 1 (HTLV-1) infection is based on serology and PCR. The burden of HTLV-1 viral infection is monitored by measuring the proviral load [PVL] in peripheral blood. This assay is not useful for isolation of HTLV-1-infected cells. HTLV-1 Tax upregulates CD25 expression on infected $\mathrm{CD} 4+\mathrm{T}$ cells. However, CD4+CD25+ is also the phenotype of activated $\mathrm{T}$ cells. CCR4 is a chemokine receptor expressed on subsets of activated T cells. HTLV-1-infected cells secrete the CCR4 ligand CCL22, and preferentially infect CCR4+ Cells. We studied the expression of CD25 and CCR4 in lymphocytes and its relation to PVL. We performed 11-colour immunophenotyping and HTLV-1 PVL quantification on 53 samples obtained from 36 HTLV-1 infected patients, [10 asymptomatic carriers (AC); 11 patients with HTLV-1-associated myelopathy (HAM); 4 co-infected with HIV; 11 with chronic/smouldering adult T-cell leukaemia/lymphoma (ATL)] and 3 uninfected individuals. Increased frequency of CD25+ CCR4+ T cells [median: $14.7 \%$, range: $1.95-91.3 \%$ ] was observed in all HTLV-1 infected patients; the frequency correlated with PVL [Spearman $\mathrm{r}=0.89, \mathrm{P}<0.001$, Linear $\left.\mathrm{R}^{2}=0.61\right]$. CD4+ and CD8+ cells from 12 patients [6ACs and 6 HAMs] were separated for PVL estimation. CD25+ CCR4+ cell counts correlated closely with PVL in CD4+ cells [Spearman $\mathrm{r}=0.816, \mathrm{P}<0.001$, linear $\mathrm{R}^{2}=0.886$ ] but not in CD8+ cells. Frequency of CD25+CCR4+ T cells correlated with PVL change in treated ATL patients. We conclude that CD25+CCR4+ cells can be used as a specific marker for monitoring of HTLV-1 infection and isolation of HTLV-1 infected cells.

Published: 7 January 2014

* Correspondence: hkagdi@imperial.ac.uk

Infectious Diseases and Immunology, Faculty of Medicine, Imperial College, London, UK

C Biomed Central

(0) 2014 Kagdi et al; licensee BioMed Central Ltd. This is an Open Access article distributed under the terms of the Creative Commons Attribution License (http://creativecommons.org/licenses/by/2.0), which permits unrestricted use, distribution, and reproduction in any medium, provided the original work is properly cited. The Creative Commons Public Domain Dedication waiver (http:// creativecommons.org/publicdomain/zero/1.0/) applies to the data made available in this article, unless otherwise stated.
doi:10.1186/1742-4690-11-S1-P139
Cite this article as: Kagdi et al: CD25+CCR4+ cells as a marker of

HTLV-1-infected cells in peripheral blood. Retrovirology 2014 11(Suppl 1): P139. and take full advantage of:

- Convenient online submission

- Thorough peer review

- No space constraints or color figure charges

- Immediate publication on acceptance

- Inclusion in PubMed, CAS, Scopus and Google Scholar

- Research which is freely available for redistribution 